\title{
SURABAYA OLD TOWN NEW LIFE: RECONSTRUCTING THE HISTORIC CITY THROUGH URBAN ARTEFACTS
}

\author{
PUTERI MAYANG BAHJAH ZAHARIN \& NOOR IZZATI MOHD RAWI \\ Centre of Studies for Architecture, Faculty of Architecture, Planning and Surveying, \\ Universiti Teknologi MARA, Malaysia
}

\begin{abstract}
Architecture portrays the physical and visible image of a place. From these images, its meanings represent the transformation and development of a city over time. Architecture is continuously remodelled to adapt to the development and modernisation that a city and its society experience. The Old Town of Surabaya is well known for its cultural diversity with its distinctive six main district settlements along the Kalimas River namely the Arabic, Chinese, Javanese, Dutch, Industrial area and Business and Service area. In line with the government efforts to revitalise the old town, the architecture of this part of the city needs to be remodelled and altered to realize the government's vision and to revive the identity of this district. For example, the warehouse, which is an urban artefact and one of the most significant typology built along the Kalimas River during the era of Surabaya as an entrepot, is now neglected and portrayed a derelict image to the old town's identity and memory. This paper intends to explore how architecture expresses the identity and memory of the city of the Old Town of Surabaya. By investigating the experience in the old town, the typology of the town is defined and urban artefacts are identified. Then, the warehouse, which is one of the urban artefacts in the old town, is discussed in terms of its transformation, typology, memory, and how its existence can define the identity and memory of the old town.
\end{abstract}

Keywords: historic city, urban artefacts, architecture and the city, collective memory, typology, warehouse, transformation, identity.

\section{INTRODUCTION}

Surabaya is the second largest city in Indonesia and is the capital city of East Jawa. The city is famously known as the "City of Heroes" due to the historic battle during the revolution of Indonesia. Surabaya was once a trading centre and port rivalling Batavia during the Dutch era. The history of Surabaya, in general, can be categorised into three periods [1]; Surabaya as a Palace City, Surabaya during Colonization and Surabaya after Independence.

\subsection{Surabaya as a Palace City}

During the $14^{\text {th }}$ century, the king of Majapahit decided to develop Surabaya as an entrepot which later became a major political and military power. In the $16^{\text {th }}$ century, Majapahit collapsed and Surabaya was taken over by the Mataram Kingdom. During the Mataram ruled, a keraton (palace) was built on the southern part of the city. This ancient palace as a dominance of centralized sovereignty was then diminished by colonial insertion of foreign city planning models during the Dutch occupation.

\subsection{Surabaya during colonization}

Surabaya was colonized by the Dutch East India Company (VOC) from the weakened Mataram in the 17 th century. It was during this period that Surabaya became a major trading centre and a naval base. As a centre for trade, foreign workers were brought in and 
foreign traders that settled in Surabaya became the onset of the cultural and ethnics diversity in this city. VOC grouped the ethnic into four separate settlements along the Kalimas River [1], with Arabs in the north, Malay in the south, Chinese near Kembang Jepun and Dutch in the western part of the river. These strong characters of the four settlements became the main features of the Old Town of Surabaya. After the World War II, the Indonesian militants battled against the British armed forces to fight for independence. This confrontation or commonly known as the Surabaya Battle has popularized the identity of this city as the "City of Heroes".

\subsection{Surabaya after independence}

Since then, Surabaya has continuously developed, transformed, flourished and modernised over time. Besides being called as the "City of Heroes", Surabaya is also known as the city of Budipamarinda [2], which stands for the City of Industries, Commerce, Maritime, Education, Garrison and Tourism. However, due to the memory of the epic battle that is strongly being remembered by its society till today, the significance of Surabaya as the "City of Heroes" remains to stand tall.

\section{THE OLD TOWN OF SURABAYA}

The old town is the first inner district of Surabaya [1]. This area is formerly known as a port city and a trading centre during the Majapahit Kingdom. In the era of the Palace City, many foreign traders from the Middle East and China came to the old city to trade. Some of them even decided to settle down in Surabaya which, influenced the growth of the Arab Quarters and Chinatown in the inner city. It was during the Dutch occupation that trade and port function flourished causing the colonizers to reorganize the residential area based on ethnicity and building function. For this reason, the old town was categorised into six different districts namely the Arab Camp, Chinese Town, Industrial Area which consists of the warehouses, Dutch Kampong, Business and Service Area and Surabaya Kampong of Malay settlements.

The old town lost its centrality when the infrastructure developments and the city centre of Surabaya were shifted to a new area near Tunjungan [3]. The introduction of the Industrial Allotment Policy in the mid-70s has put limitations in the expansion of industrial activities that brought to the deterioration of this part of the city. However, with the current vision to revive the old town for tourism purposes, new initiatives such as bus tour that connects the House of Sampoerna that is located in the old town to the new city centre are introduced. This approach has allowed people and tourists to explore and experience the old townscapes.

In the historic city of Surabaya, the environment, streets, buildings and the architecture become the valuable artefacts that project the identity and narrate the memory of its inhabitants. Hence, in order to ensure the success of the revival of the old town, the identity, image and memory of the neglected and run-down facade and buildings of this part of the city must be revisited.

\section{ARCHITECTURE AND THE CITY}

Many theorists have explored the city in utilitarian, functional and to its constructional dimension. Mumford [4], discusses the idea of city as a work of art. Similar to Mumford, Aldo Rossi conceptualizes city as an artefact. Rossi's theory of city goes beyond the urban pattern and meanings that enable exploration of architecture as the main construction of the city that serves beyond aesthetic dimension [5]. 

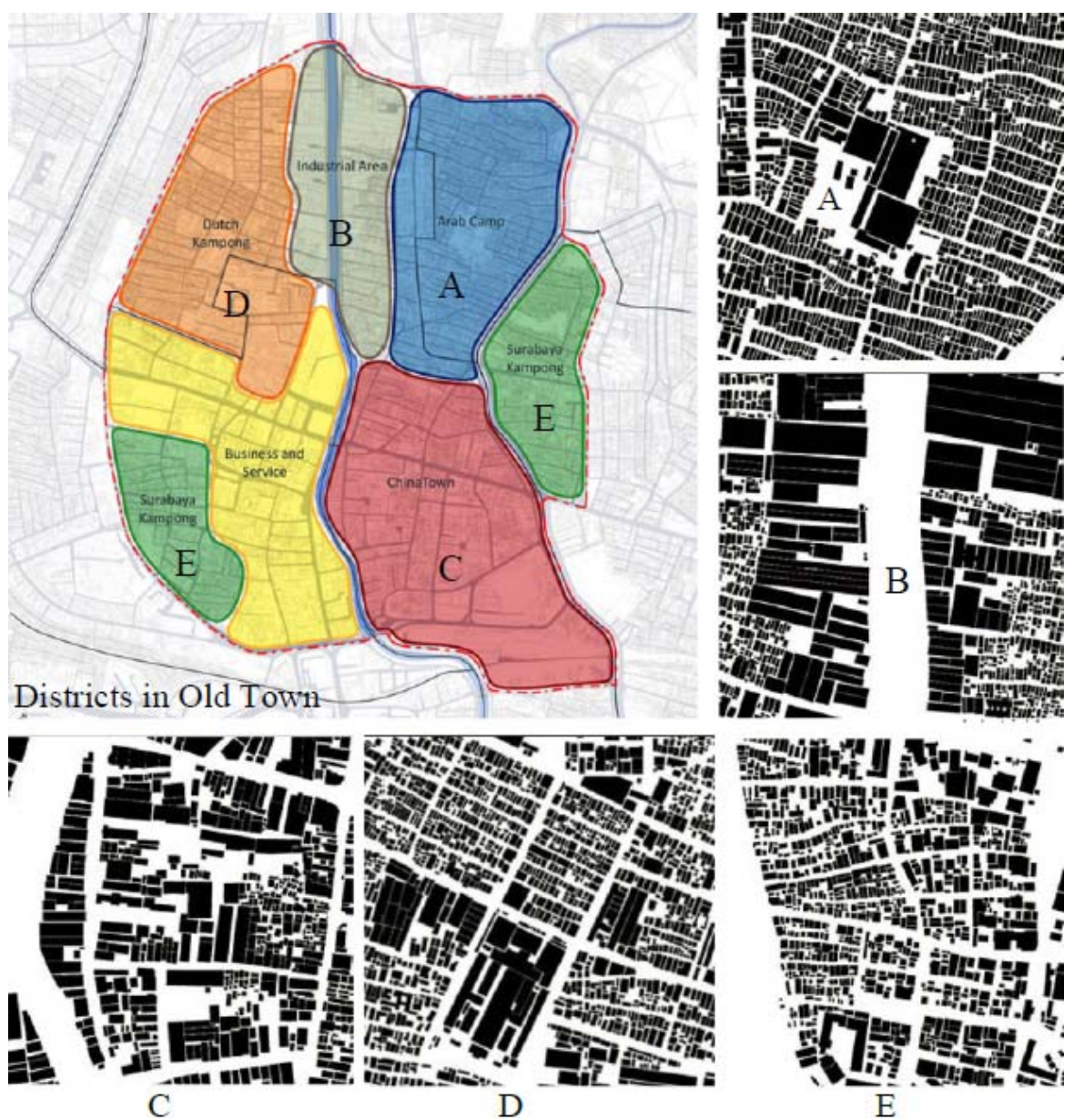

Figure 1: Districts and figure ground of the old town. (Source: Hadi, 2011.)

\subsection{Theory of city}

According to Blumenfeld [6], theory has tended to emphasize city into two poles; either as a whole or one big unit or a sum of many small units. Rossi [7], considers city as unified elements, a gigantic manmade object and a construction of different parts. Yet, he also recognizes city's singular places (locus solus), which he describes as elements of consistency and permanence among the process of urban dynamic. This includes monuments and the permanent, fixed points and signs of the collective memory. According to Rossi's idea of city evolution [7], "the form of the city is always the form of a particular time of the city but there are many times in the formation of the city". Rossi develops his understanding of the city by considering the relationship between the typology of building and city and views these buildings as monuments that form part of the city. Following this, Rossi explores the structure of the city where he then focuses on architecture as the main construction of the city. 


\subsection{Urban artefacts and the city}

Urban artefacts as defined by Rossi et al. [7], constitute not only buildings but fragments of the city in which each of these elements have its own complexity that is possible to analyse but is hard to define. According to Eisenman [8], the physical context of a city together with the history, geography and structure, form part of the urban artefacts. As city grows within the physical, historical, geographical and structural context, these formation and transformation produce different artefacts that revolve over time.

Owing to these ambiguities, Rossi describes that the main characteristics of urban artefact lies collectively and permanence in its historical character of artefacts. Buildings with special character may transform into artefacts that specify certain typology. In addition, different buildings signify different characters or individuality that within time, may contrast in its existence [7]. A building may also hold multiple functions either independently or dependently from the changes in its form that influence the structure of a city. The development of the city about these artefacts as noted by Rossi et al. [7], defines the context of "urbanism".

\subsection{Collective memory and identity of the city}

Cities experience events and acquire memory over time. There is always a sort of exchange between cities and its inhabitants; the interaction with its occupants and how architecture narrates the memory by simply dwelling in it, traversing it or looking at it [5]. Rossi believes that a city is the collective memory of its people, a stage where the human activities take place and the imprints left by these people.

Although Rossi does not distinctly discuss identity in his text, he however highlights the different factors and quality that give a city its distinctive identity such as permanence, urban artefacts, time, typology, collective memory and the locus solus; the singular component within a city. According to Lee [9], city is always considered as a man-made object and that the past will always be partly experienced and gives meaning to permanence. The experience of this permanence can be in the existence of form and its propelling and pathological elements.

A city can also be understood through its architecture [7]. Although architecture can be transformed, altered and remodelled through the development of a city, it provides evidence of the city's survival and resilience. A city does not tell its past [5], but the memories are embedded within the urban artefacts. The identity of a city is dynamic and can be constantly changed to adapt to the changing nature of the city. In addition, the experience of a city is often narrated through its architecture. Despite the ability to transform, architecture can also be in a constant form of urban artefacts that bring the city to its past.

\subsection{The city through its type and typology}

The general understanding of type in architecture often refers to the usage of buildings. In theoretical context, Rossi et al. [7], defines type as "the very idea of architecture that is closest to its essence and always imposed itself on the feelings and reasons as the principle of architecture and of the city". This principle that underlies type as noted by Rossi, can be found in urban artefact. According to Lee [9], the notion of type has commonly been linked to typology as a design method in the early 19 th century.

The distinctiveness of a city lies in its typology, classification and characteristic. Similar to Rossi, Vidler [10], recognizes city as a whole and that all elements in the city such as 
buildings, streets and urban spaces are connected by a chain of continuity and meaning. Vidler in his Third Typology divides typology into three categories. The First Typology describes the primitive hut; nature as origin, city as the forest and the built environment as a tree structure. The Second Typology is based on the industrial development in the $19^{\text {th }}$ century where buildings are machine-analogous, and mass produced. The Third Typology is introduced to break the Modern Movement. It defines city as architecture, has permanence and collective memory of its inhabitants, an artefact and collection of types. There is no clear set of rules for the transformation of a city. The transformation in general rests within the demands of the present.

Neo-rationalists used types and typology to understand the historical aspects and inner structure of a city and improve design through continuity between the old and new designs of the historical city [11].

\section{URBAN ARTEFACTS: OLD TOWN OF SURABAYA}

According to Rossi et al. [7], the most significant urban artefacts are housing and monuments. Transformation of these artefacts symbolises the evolution in terms of time and collective memory of the city.

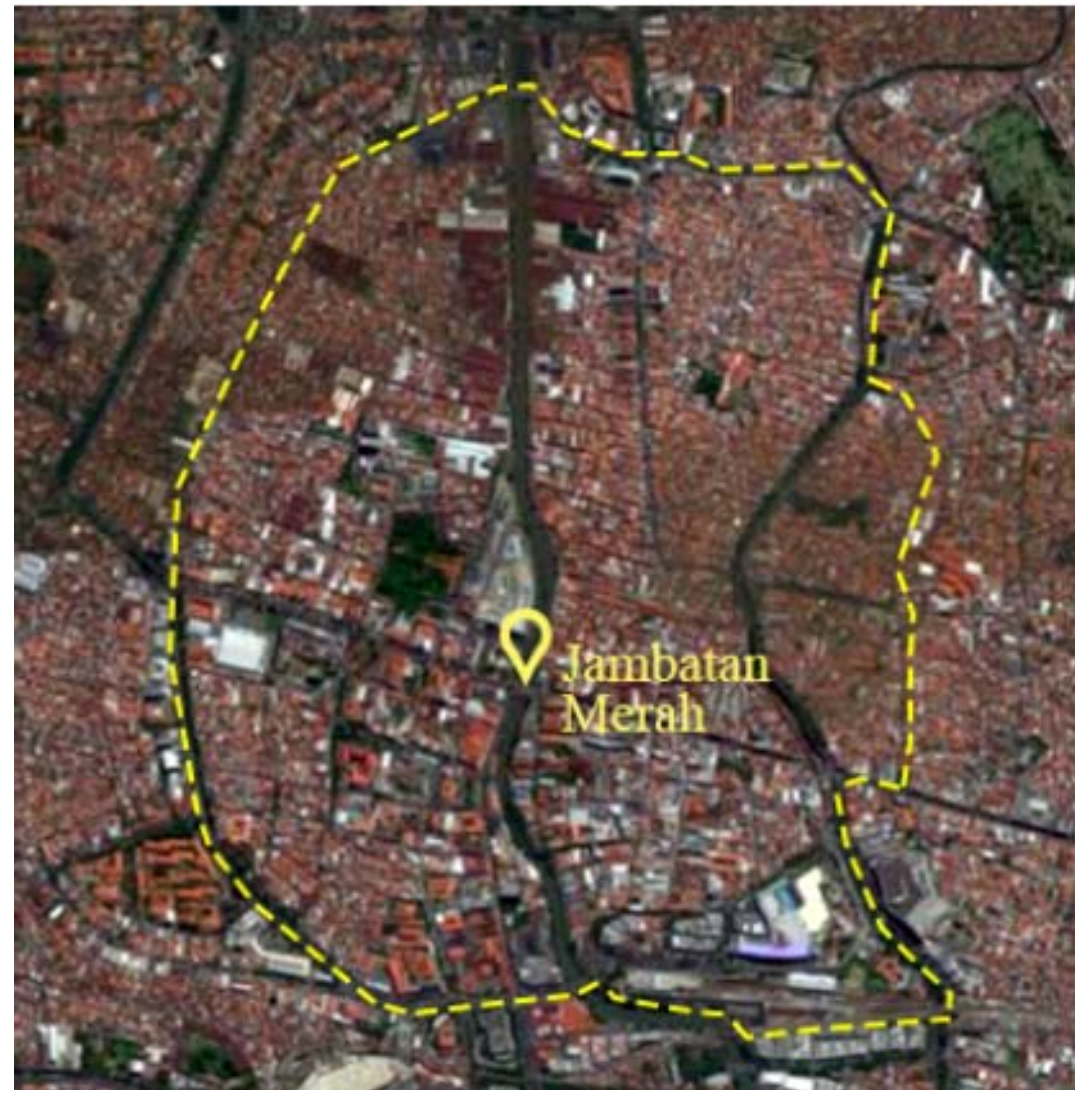

Figure 2: Map of the current boundary of the old town. 
During the era of Palace City and Dutch occupation, Surabaya thrives as a centre for trade and port. Many foreign traders and neighbouring locals came to trade and some even settled in Surabaya. This caused the area along the port; the Kalimas River to expand and develop into six major settlements as discussed earlier in the old town [3].

These six residential areas form the most distinctive urban artefacts in the Old Town of Surabaya. The significance of these residential areas can be seen in its structural character, typology and repetition [12]. Each area has its own character, figure ground (Fig. 1), street and environment.

Unlike the repetitive character of housing as urban artefact, monuments owe their singularity to their character of permanence, acting as primary elements as fixed point amidst the urban dynamic [12]. To accommodate these neighbourhoods, infrastructures such as mosques, churches and town halls were built. These infrastructures provide symbolic anchor point for the religions and political identity of the urban areas. Due to its unique structural character and architecture, these infrastructures became urban artefacts to the current old town; manifesting the glories of the past trade and port city. Some of these artefacts were developed into monuments; some were transformed to hold different functions and some still served the same functions; bringing the current inhabitants to experience the lifestyles of the past inhabitants.

People visualize a city based on its dominant culture or architecture. The pictures above portray the unique identity of the Old Town of Surabaya through its different types of architecture and building typologies.

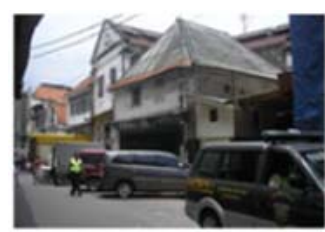

Arab Camp

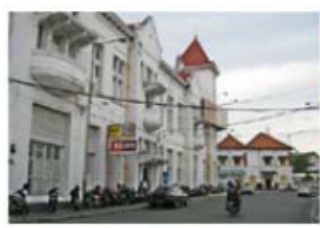

Business area

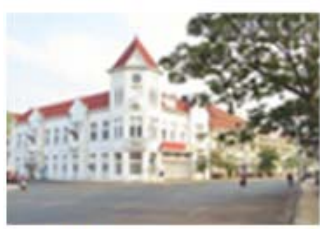

Clock Tower

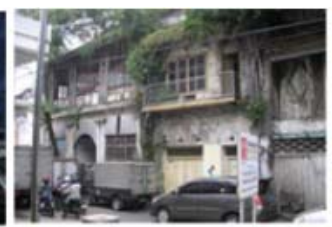

Chinatown

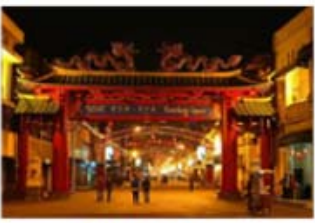

Kya-Kya

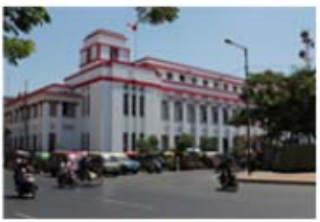

Former AIA Bureau

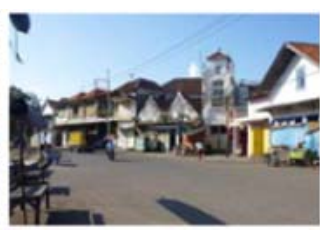

Warehouses

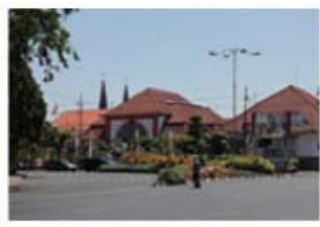

Post Office (Governors' House 1928)

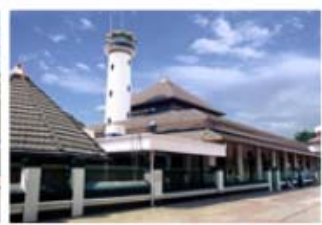

Masjid Ampel

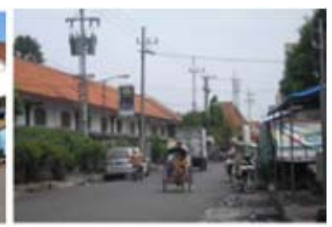

Dutch Kampong

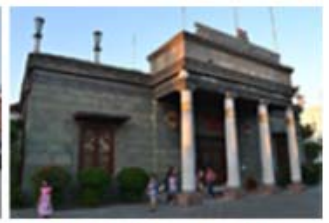

House of Sampoerna

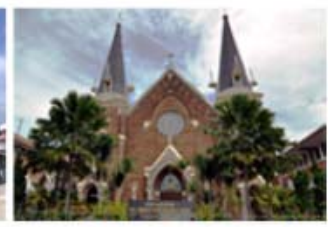

Santa Maria Church

Figure 3: Urban artefacts of the Old Town of Surabaya. 


\section{THE WAREHOUSE}

Kalimas River plays an important role in shaping the character of Surabaya City. Since the $18^{\text {th }}$ century, the river holds the longest harbour equipped with thousands of warehouses and factories surpassing the numbers in Batavia (currently known as Jakarta) [13]. The remains of this triumph are reflected in the $19^{\text {th }}$ century warehouses located in the industrial district of the old town of this city. These warehouses act as a physical memento of the economic growth in that era. Unlike the residential areas and shop houses, these warehouses have been neglected since the mid-70s due to the introduction of the Industrial Allotment Policy [3].

To realize the government's vision in reviving the identity and image of the old town for tourism, the neglected warehouses located at the upper middle of the town must be revitalised. These warehouses hold an important urban artefact that creates memory of the past trade and port.

Rossi et al. [7], describes that if the urban artefacts were constantly able to reform and renew by simply establishing new functions, its values as urban structure would be continuous through architecture.

The warehouses in the old town have strong structural character that differ from the Arab Camp and the Dutch Kampong located at the side of the river. The plausible initiative is to adaptive reuse the warehouses with different function as opposed to its original function as storage area.

The transformation of the urban artefacts which in this case, the warehouses, is needed to accommodate the city's vision and at the same time holds the memory of the past.

The uniqueness of its architecture needs to be identified to ensure that new designs do not oppose the permanence character of these warehouses.

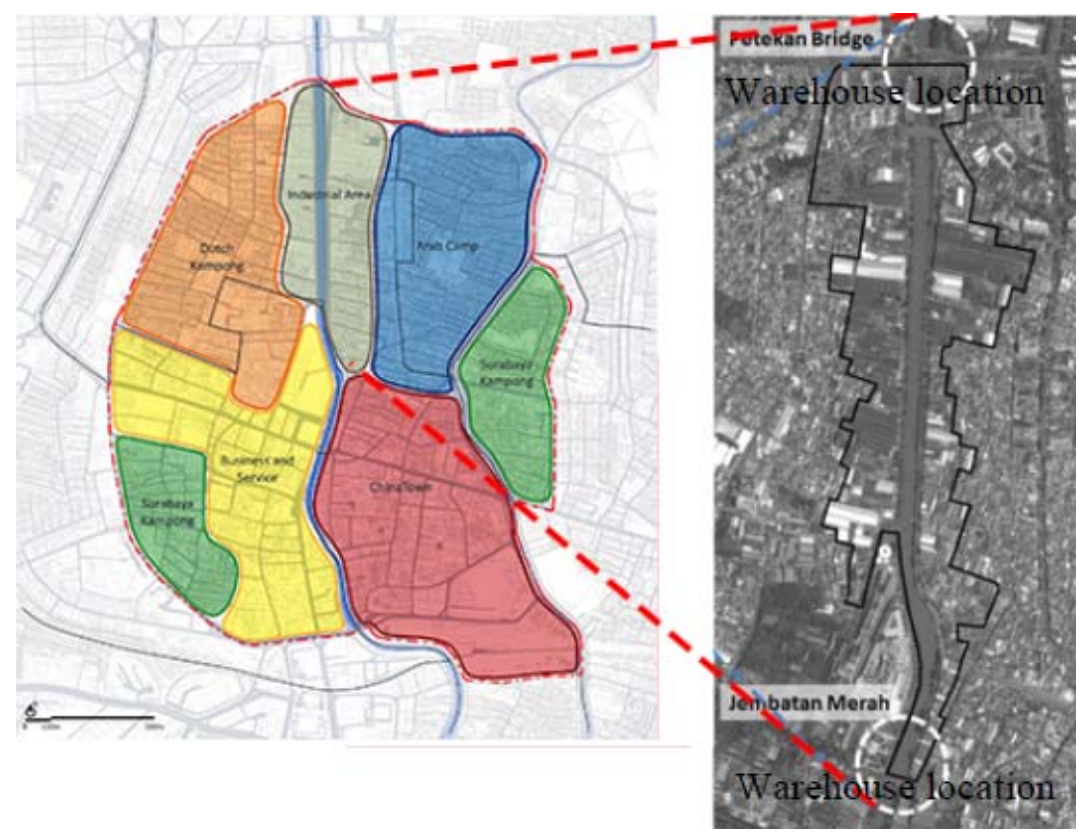

Figure 4: Location of warehouses in the Industrial District of the Old Town of Surabaya. (Source: Left: Hadi, 2011; Right: Darjosanjoto et al., 2015.) 
Table 1: Structural character of warehouses along the eastern Kalimas River. (Source: Darjosanjoto et al., 2015.)

\begin{tabular}{|l|l|}
\hline Mark "A" in Segment 1, Fig. & $\begin{array}{l}\text { Jengki architecture style that arose around } \\
\text { 5 }\end{array}$ \\
\hline $\begin{array}{l}\text { Mark "B" } 1960 . \\
\text { Segment 5, "C" in }\end{array}$ & $\begin{array}{l}\text { The buildings marked are the historical } \\
\text { harbourmaster tower. These buildings are } \\
\text { Fig. 5 }\end{array}$ \\
\hline $\begin{array}{l}\text { Segment "2", "3", "4" and } \\
\text { "6" in Fig. 5 }\end{array}$ & $\begin{array}{l}\text { The warehouses have similar architecture } \\
\text { elements to the Arab Camp. }\end{array}$ \\
\hline
\end{tabular}
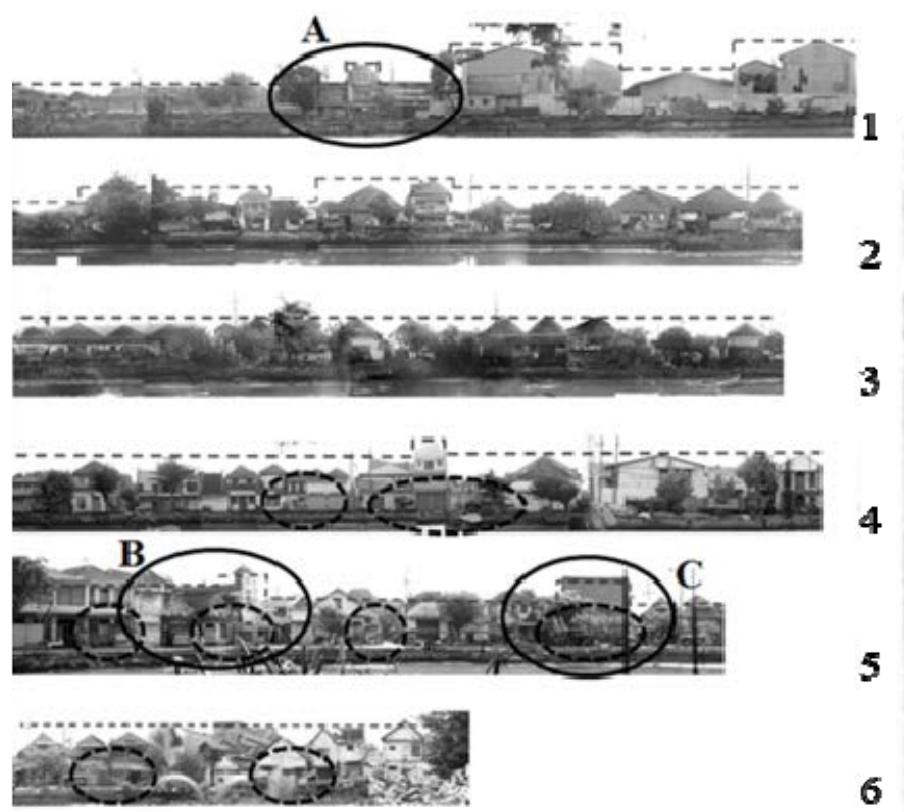

2

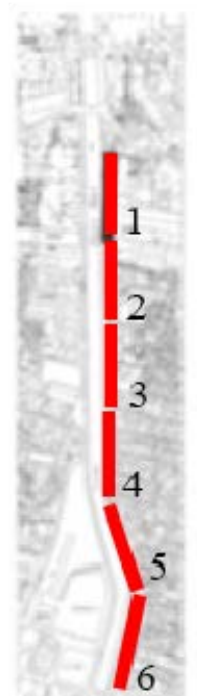

Figure 5: Street pictures of the eastern Kalimas River. (Source: Darjosanjoto et al., 2015.)

Table 2: Structural character of warehouses along the western Kalimas River. (Source: Darjosanjoto et al., 2015.)

\begin{tabular}{|l|l|}
\hline $\begin{array}{l}\text { Mark 'D' and 'E' in Segment 2, } \\
\text { Fig. 6 }\end{array}$ & $\begin{array}{l}\text { The warehouses have no specific architectural } \\
\text { style but the gable roof provides distinctive } \\
\text { character along the street. }\end{array}$ \\
\hline $\begin{array}{l}\text { Mark "C" in segment 5, Fig. 5 } \\
\text { and mark "F" in Segment 5, Fig. } \\
6\end{array}$ & $\begin{array}{l}\text { The warehouses are run-downed. No clear } \\
\text { structural character of these warehouses. }\end{array}$ \\
\hline Segment 1,3 and 4 in Fig. 6 & $\begin{array}{l}\text { Despite being located next to the Dutch Kampong, } \\
\text { the warehouses show no distinctive character. }\end{array}$ \\
\hline
\end{tabular}




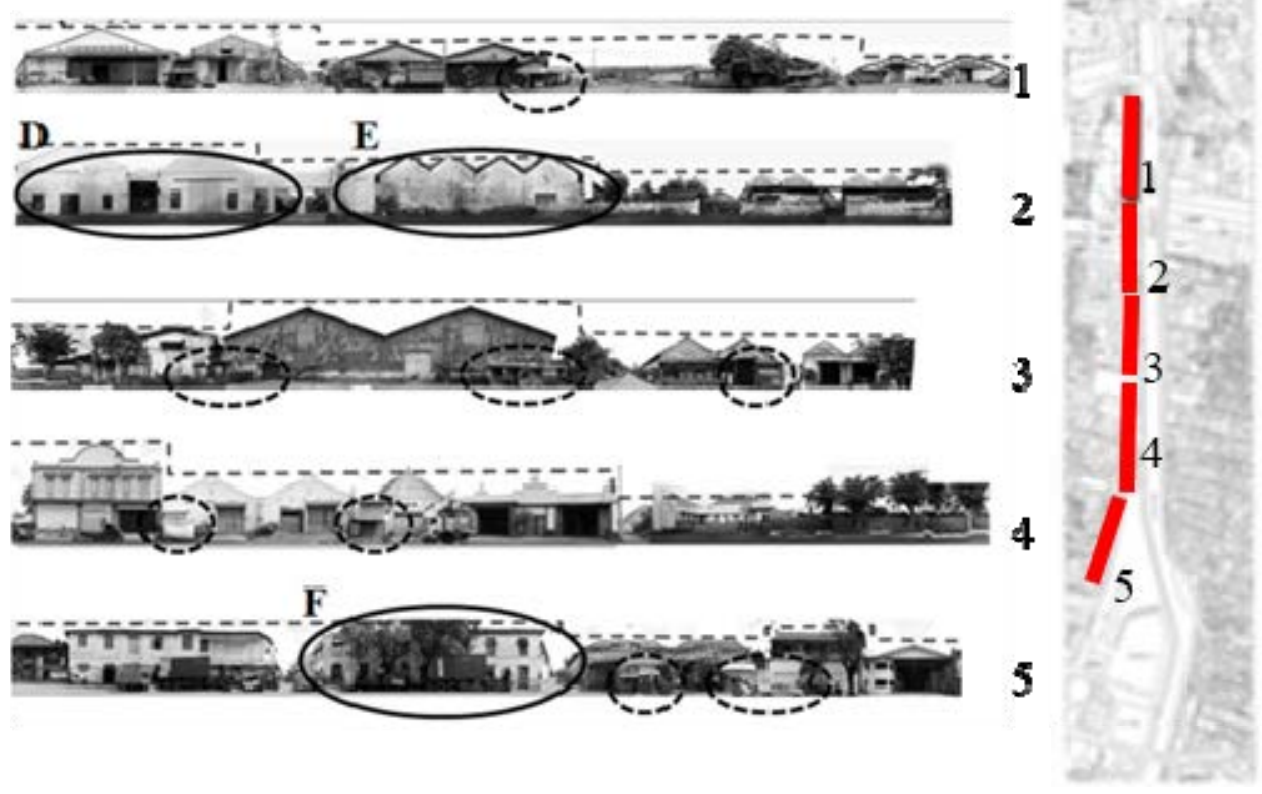

Figure 6: Street pictures of the western Kalimas River. (Source: Darjosanjoto et al., 2015.)

Different buildings possess its own identity and have different capacity that may transform and change over time [5]. The warehouses in the Old Town of Surabaya which were once served as a storage area are now long being neglected [13], creating a deteriorating illusion in this part of the city. Despite its dilapidated state, particularly on its architectural elements, these warehouses actually added to the unique character of this old town. It also expresses the glorious period of Surabaya during the 17th century.

Although the warehouses in the old town are obsolete for its original function, the permanence character of these warehouses remains significant. Set against the residential buildings, its prominence lies in its remarkable structures and huge volume and space [13].

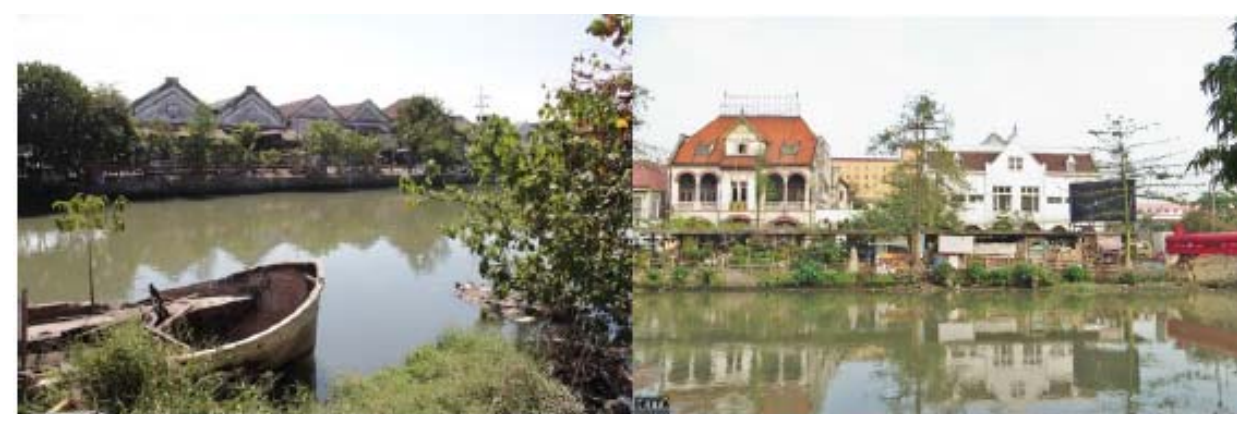

Figure 7: The Dutch godowns on the western side of Kalimas River. (Source: Left: https://dreamofacity.com/2012/09/23/colours-of-old-town-east-surabaya/;

Right:http://www.skyscrapercity.com/showthread.php? $t=1372277 \&$ page=19.) 


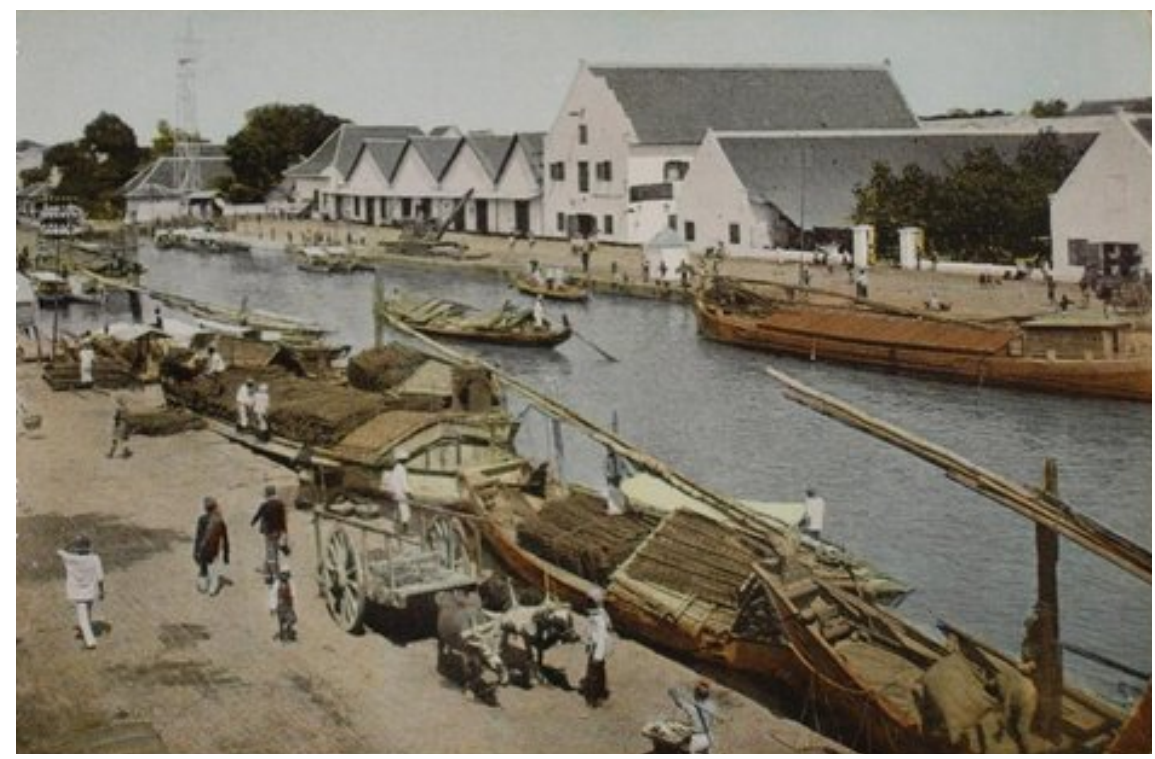

Figure 8: A drawing illustrating the godowns on the western side of Kalimas River during the 19th century. (Source: http://surabayaenvironment.weebly.com/4/category/ majapahit\%20kingdom/1.html.)

The warehouses in the Old Town of Surabaya have witnessed several transformations; from the era of Palace City to the modern era after independence [13]. However, when these buildings were left neglected, the memory of the city's past and events slowly diminished as it could no longer be narrated through its unique structural character and other distinguished urban artefacts (Figs 7 and 8) [3].

Urban artefacts may transform to accommodate the changing nature and demands of the city [7]. Hence, in order to revive the Kalimas riverbank in the Old Town of Surabaya, the symbolic nature of the warehouses in terms of its character, functions and architecture must be emphasized although at times, it may be remodelled and altered to suit the current needs. While adaptive reuse may be the best option, the typology of functions and programs to be injected into these warehouses must be appropriate to its context and identity of the old town to ensure continual memory of this historic city [10]. The transformation of these warehouses must also take into account the ambience of the past and the present. The neglected and slump like environment of the warehouses is needed to be revived up to the liveliness and busy atmosphere of once a port and trade centre. The act of revisiting these warehouses would help to alleviate the collective memory of the past. For instance, converting the industrial warehouses into public and commercial use to increase the vibrancy of public and commercial events, urban space and local growth [12].

\section{CONCLUSION}

By reconstructing and mapping the urban artefact of the historic city, the old town and the inner part of the city can be further appreciated [5]. The urban artefacts unveil the importance of collective memory throughout their survival and resiliency. Despite having great function and location, urban artefacts acquire strong collective memory in 
shaping a city's identity. In other words, city is a depot of collective memory and identity [5].

As the city remodelled to suit the changing nature and current needs, reconciliation between the city and its inhabitants occurs. This can be verified through the city's architecture, which forms the basic component of a city [7].

In the case of the Old Town of Surabaya, the current government has taken initiatives to revive this part of the city. As such, the warehouse, which is one of the important urban artefacts in the old town, must be revisited. New functions need to be introduced into this building, giving suggestion that the identity of a city is never identical.

\section{REFERENCES}

[1] Arifin, L.S., The Lost of "Jagad Cilik": Exploring Memory, Structuring Meaning the Modernity of Surabaya City, fportfolio.petra.ac.id/.../The\%20Lost\%20of\%20Jagad \%20cilik\%20\%207th\%20mAA. Accessed on: 13 May 2017.

[2] Ferita, H.D., City report of Surabaya. Presented at AUICK First 2006 Workshop, 2006.

[3] Hadi, H., The New Life in Old Town Surabaya: Preserving the Urban Heritage Through Space Revitalization, Thesis report, TuDelft, 2011.

[4] Mumford, L., Culture of Cities, Harcourt, Brace \& World, New York, 1938.

[5] Yaser, D.J., Architecture and the City Ramallah's Changing Identities, Master thesis, Pennsylvania State University, 2009.

[6] Blumenfeld, H., Theory of city form, past and present. Journal of the Society of Architectural Historians, 8(3),(4), pp. 7-16, Jul.-Dec. 1949.

[7] Rossi, A., Eisenman, P., Ghirardo, D. \& Ockman, J., The Architecture of the City, MIT Press Cambridge, MA, 1982.

[8] Eisenman, P., Introduction: Urban artifacts and a theory of the city. The Architecture of The City, Aldo Rossi, MIT Press Cambridge, MA, pp. 21-28, 1982.

[9] Lee, C.C.M., The City as a Project, http://thecityasaproject.org/2011/08/type/. Accessed on: 28 Jul. 2017.

[10] Vidler, A., The third typology. Oppositions Reader, ed. P. Eisenman et al., Princeton Architectural Press, pp. 13-16, 1998.

[11] Parlak, N., Typological Residential Urbanism: An Alternative Analysis of the Toki Housing Production As a Dominant Type, Thesis report, Middle East Technical University, 2015.

[12] Mauer, M., The Soul of The City, http://marcelmauer.eu/spaceupdecarb/ 2017/01/07/the-soul-of-the-city/. Accessed on: 28 Jun. 2017.

[13] Darjosanjoto, E.T.S., Nugroho, S. \& Danardi, R.W., Design criteria in revitalizing old warehouse district on the Kalimas riverbank area of Surabaya City. Journal of Visual Art and Design, 7, pp. 55-67, 2338-5480, 2015. 